\title{
Extracellular Calcium and Induction of Uterine Muscle Contraction by Aqueous Ethanolic Leaf Extract of Mucuna pruriens
}

\section{${ }^{1}$ FRANCIS, B; ${ }^{2}$ UCHENDU, CN; ${ }^{2}$ OBIDIKE, RI}

\author{
${ }^{*}$ Department Of Veterinary Physiology and Biochemistry, University of Benin, Benin city, Edo State, Nigeria. ${ }^{2}$ Department of Veterinary \\ Physiology \& Pharmacology, University of Nigeria, Nsukka. Enugu State, Nigeria. \\ *Corresponding Author Email: blessing.francis@uniben.edu; Tel: +2348030713997 \\ Other Authors Email: chukwuka.uchendu@unn.edu.ng,Tel: +234 8060375626; ikechukwu.obidike@unn.edu.ng; Tel: +2348063276354
}

\begin{abstract}
Calcium $\left(\mathrm{Ca}^{2+}\right)$ serves as an essential signaling molecule in biological systems, regulating a wide range of cellular processes of which uterine smooth muscle contraction is among. The present study was designed to evaluate the involvement of $\mathrm{Ca}^{2+}$ on isolated uterine muscle contraction induced by aqueous ethanolic leaf extract of Mucuna pruriens (M. pruriens). Uterine muscle contraction induced by the extract was concentration-dependent and was completely abolished $(100 \% ; \mathrm{P}<0.05)$ in nominally $\mathrm{Ca}^{2+}$-free physiological salt solution and in solutions containing (EGTA $1.5 \mathrm{mmol}$ ), lanthanium chloride (1.5 and $3 \mathrm{mmol}$ ), caffeine (3and $4.4 \mathrm{mmol})$ and verapamil $(0.007$ $0.14 \mu \mathrm{mol})$. It is concluded that the inability of the extract to produce contractions in $\mathrm{Ca}^{2+}$-free media, indicates that it lacks the ability to mobilize calcium from intracellular storage sites. Hence, its uterine stimulatory property is therefore solely dependent on extracellular $\mathrm{Ca}^{2+}$.
\end{abstract}

DOI: https://dx.doi.org/10.4314/jasem.v24i2.6

Copyright: Copyright $($ C 2020 Francis et al. This is an open access article distributed under the Creative Commons Attribution License (CCL), which permits unrestricted use, distribution, and reproduction in any medium, provided the original work is properly cited.

Dates: Received: 16 November 2019; Revised: 11 January 2020; Accepted: 22 February 2020

Keywords: Calcium, Mucuna pruriens, Uterus, Contraction.

Regulation of $\mathrm{Ca}^{2+}$ flux across the plasma membrane is essential in skeletal and smooth muscle contractile activities. Regardless of the stimulus, smooth muscle cells use $\mathrm{Ca}^{2+}$ as a second messenger signaling molecule to initiate cross-bridge cycling between actin and myosin to develop force (Webb, 2003). This is referred to as excitation-contraction coupling (Bilge et al., 2013). Elevation of cytosolic $\mathrm{Ca}^{2+}$ is through $\mathrm{Ca}^{2+}$ release from intracellular stores such as the sarcoplasmic reticulum (Izumi,1994), as well as entry from the extracellular compartment in response to specific stimuli elicited by different agonists or by electrical depolarization (Webb, 2003). The action potential embodied by membrane depolarization initiates many intracellular events seen in all excitable tissues. This is also the case in smooth muscle cells where plasma membrane depolarization leads to the entry of extracellular $\mathrm{Ca}^{2+}$ leading to the elevation of cytosolic $\mathrm{Ca}^{2+}$ (Wray et al., 2003). Mucuna pruriens belongs to the Family- Fabaceae (Sharma et al., 2012). It is a twinning and tropical legume known as velvet bean with other common names such as Agbara (Igbo), Yerepe (Yoruba), Karara (Hausa), itchy bean and many others (Eze et al., 2012). All parts of $M$. pruriens possess valuable medicinal properties (Adepoju and Odubena, 2009). Roots, leaves and seeds of the plant are used to treat different ailments such as impotence, snake bite, diabetes, cancer and Parkinsonism (Dhanasekaran et al., 2010). In a previous study, it was established that the aqueous ethanolic leaf extract of Mucuna pruriens has ability to cause uterine smooth muscle contraction (Francis et al., 2019). In the present study, the role of $\mathrm{Ca}^{2+}$ on $M$. pruriens -induced uterine smooth muscle contraction in albino rat was investigated.

\section{MATERIALS AND METHODS}

Extraction studies: Fresh leaves of Mucuna pruriens were collected and identified by a taxonomist at Bioresource Development and Conservation Center (BDCC), Aku road Nsukka, Enugu state of Nigeria with voucher No-INTERCEDD/1569. The leaves were air dried and pulverised into fine powder, using a conventional hammer mill. This was subjected to cold extraction initially using petroleum ether (70-90) for 72 hours and later with $70 \%$ aqueous ethanol for 48 hours with intermittent shaking at two (2) hours interval. The extracts were allowed to dry at room temperature and subsequently stored in the refrigerator at $4^{\circ} \mathrm{C}$.

Animals: Non-pregnant Albino rats of breeding age, weighing between $180 \mathrm{~g}$ and $250 \mathrm{~g}$ were used for the in vitro bioassay studies. The rats were supplied by a 
breeder and kept at the Laboratory Animal Unit of the Department of Veterinary Physiology, Michael Okpara University of Agriculture, Umudike, Nigeria. Standard commercial pelleted feed (Vital feeds, Nigeria) and clean drinking water were given to the animals ad libitum. Each of the rats received $0.1 \mathrm{mg} / \mathrm{kg}$ stilboestrol in paraffin oil administered subcutaneously 24 hours prior to the experiments.

Tissue Preparation and Isometric Contraction studies: The animals were sacrificed by stunning and decapitation. About $12 \mathrm{~mm}$ segment of uterine horn was removed and attached by ligatures at one end to a specimen holder and at the other to an isometric force displacement transducer (Forte transducer Medicaid, India) connected to a physiogragh. This was suspended vertically in a $35 \mathrm{ml}$ conventional organ bath containing physiological salt solution of the following composition (mmol): $\mathrm{KCl}$ (4.7); $\mathrm{NaCl}$ (118); $\mathrm{KH}_{2} \mathrm{PO}_{4}$ (1.2); $\mathrm{NaHCO}_{3}$ (2.5); $\mathrm{CaCL}_{2}$ (2.5); $\mathrm{MgSO}_{4}$ (1.2); and glucose (11); and perfused continuously with a gas mixture of $95 \% \mathrm{O}_{2}$ and $5 \%$ $\mathrm{CO}_{2}$, maintained at $37^{\circ} \mathrm{C}$. All uterine strips were put under a little amount of tension and experiments started within 40 minutes following development of stable rhythmic, spontaneous uterine contractions. To obtain evidence for involvement of extracellular $\mathrm{Ca}^{2+}$ in $M$. pruriens -mediated uterine smooth muscle contraction, $\mathrm{Ca}^{2+}$-free physiological salt solution was prepared by replacing $\mathrm{CaCl}_{2}$ with EGTA (1.5 mmol incubated for five minutes for maximum chelation of extracellular $\left.\mathrm{Ca}^{2+}\right)$. Ethylene glycol bis ( $\beta$-aminoethyl ether)-N,N,N',N'-tetraacetic acid (EGTA) was omitted in experiments involving Lanthanium Chloride $\left(\mathrm{LaCl}_{3}\right)$ and caffeine; hence such solutions were considered nominally $\mathrm{Ca}^{2+}$-free. Caffeine was used to study the ability of the extract to release $\mathrm{Ca}^{2+}$ from the sarcoplasmic reticulum via $\mathrm{Ca}^{2+}$-induced, $\mathrm{Ca}^{2+}$ release( CICR) mechanism.

The uterine tissues were also exposed to the voltagedependent $\mathrm{Ca}^{2+}$ channel blocker- verapamil in physiological salt solution containing $\mathrm{CaCl}_{2}$. In all the experiments, a minimum of one (1) minute was allowed for tissue contact following which the tissue was washed three (3) times with the physiological salt solution in preparation for subsequent experiment. Concentrations of the test substances presented in the body of this work represent the final nutrient bath concentrations.

Statistical Analysis of Data: Data generated were analyzed using one-way Analysis of Variance (ANOVA). Results are presented as mean \pm standard error of the mean (SEM). Differences between the means of the control and experimental groups were considered significant where $\mathrm{P}<0.05$.

\section{RESULTS AND DISCUSSION}

Uterine muscle response in $\mathrm{Ca}^{2+}$-free physiological salt solution: In nominally $\mathrm{Ca}^{2+}$-free physiological salt solution, $M$. pruriens $(0.29-2.86 \mathrm{mg} / \mathrm{ml})$ was unable to elicit any observable uterine contraction, while uterine response to carbachol $(3 \mu \mathrm{mol})$ was significantly reduced $(\mathrm{P}<0.05)$ Table 1

Table 1: Uterine smooth muscle response to carbachol $(3 \mu \mathrm{mol})$ and graded concentrations of M. pruriens in nominally $\mathrm{Ca}^{2+}$-free and calcium containing physiological salt solutions

\begin{tabular}{|c|c|c|}
\hline \multirow[t]{2}{*}{ Extract/Drug } & \multicolumn{2}{|c|}{ Uterine muscle responses (mm) } \\
\hline & $\begin{array}{l}\mathrm{Ca}^{2+} \\
\text { free media }\end{array}$ & $\begin{array}{l}\mathrm{Ca}^{2+} \\
\text { containing media }\end{array}$ \\
\hline Carbachol $(3 \mu \mathrm{mol})$ & $3.00 \pm 0.57$ & $7.33 \pm 1.45$ \\
\hline M. pruriens $(0.29 \mathrm{mg} / \mathrm{ml}) \mathrm{n}=4$ & 0.00 & $5.00 \pm 1.73$ \\
\hline M. pruriens $(0.57 \mathrm{mg} / \mathrm{ml}) \mathrm{n}=4$ & 0.00 & $6.50 \pm 0.95$ \\
\hline M. pruriens $(1.14 \mathrm{mg} / \mathrm{ml}) \mathrm{n}=4$ & 0.00 & $4.80 \pm 1.60$ \\
\hline M. pruriens $(2.29 \mathrm{mg} / \mathrm{ml}) \mathrm{n}=4$ & 0.00 & $3.80 \pm 1.55$ \\
\hline M. pruriens $(2.86 \mathrm{mg} / \mathrm{ml}) \mathrm{n}=4$ & 0.00 & $3.30 \pm 0.63$ \\
\hline
\end{tabular}

Moreover, in $\mathrm{Ca}^{2+}$-free physiological salt solution containing EGTA (1.5 mmol), responses to carbachol were further suppressed and subsequently abolished in a fresh $\mathrm{Ca}^{2+}$-free medium (Fig 1a). In contrast, $M$. pruriens was unable to elicit any contraction in physiological salt solution containing the chelator, EGTA (Fig. 1b). This has shown that carbachol was able to elicit myometrial contraction in $\mathrm{Ca}^{2+}$-free media unlike the contraction stimulated by $M$. pruriens which was solely dependent on extracellular $\mathrm{Ca}^{2+}$ since the contraction was completely abolished in nominally $\mathrm{Ca}^{2+}$-free media and in $\mathrm{Ca}^{2+}$-free media containing the chelator EGTA. The residual contraction observed with carbachol in the $\mathrm{Ca}^{2+}$-free media seem to suggest that this uterine muscle contractant, unlike the extract was able to access $\mathrm{Ca}^{2+}$ from storage sites in the cell cytosol. That this internally stored $\mathrm{Ca}^{2+}$ is small and could easily be depleted was evident from the comparatively lower amplitude and its abolition following wash (Fig. 1a). $M$. pruriens was still unable to elicit any uterine smooth muscle contraction in nominally $\mathrm{Ca}^{2+}$-free physiological salt solution containing caffeine (4.4 mmol) Fig. 2a. On the other hand, carbachol $(3 \mu \mathrm{mol}))$ 
elicited uterine muscle response characterized by a small contraction that decayed towards the baseline in 10 seconds (Fig. 2b). The inability of $M$. pruriens to produce any uterine contraction in nominally $\mathrm{Ca}^{2+}$ free physiological salt solution containing caffeine (Fig.2a) is most likely due to the inability of the extract to utilize the CICR (calcium-release calcium-induced) mechanism to access calcium in the intracellular storage site. Previous studies on the response of rat uterine smooth muscle to caffeine also showed that caffeine lacks the ability to elicit contraction in $\mathrm{Ca}^{2+}$ free physiological salt solution (Uchendu, 1999) unlike the visceral and vascular smooth muscles (Itoh, 1981). Moreover, caffeine failed to elevate intracellular $\mathrm{Ca}^{2+}$ in cultured uterine cells (Lynn et al.,

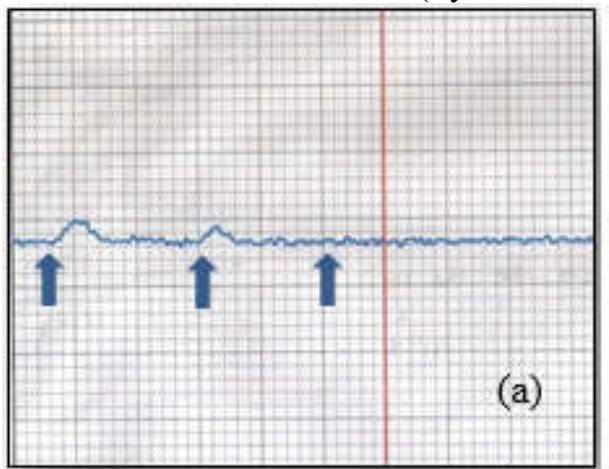

1993; Arnaudeau et al., 1994; Holda et al., 1996) and did not increase force of permeabilized or intact fibres (Savineau et al., 1990). When lanthanium chloride $(1.5 \mathrm{mmol})$ was used to block $\mathrm{Ca}^{2+}$ efflux in nominally $\mathrm{Ca}^{2+}$-free physiological salt solution, no contraction was elicited by $M$. pruriens $(0.86 \mathrm{mg} / \mathrm{ml})$ (Fig. 3a.). However, carbachol $(3 \mu \mathrm{mol})$ was able to elicit contraction in the media containing $\mathrm{LaCl}_{3}$, though no visible difference was observed in the amplitude by the different concentrations of $\mathrm{LaCl}_{3}$ (1.5 and $3 \mathrm{mmol}$ ) used (Fig. 3b). When compared, it was discovered that the uterine response stimulated by carbachol in the presence of $\mathrm{La}^{3+}$ was significantly higher $(\mathrm{P}<0.05)$ than that stimulated in the presence of caffeine and EGTA (Table 2).

Fig. 1: Uterine smooth muscle response to (a) carbachol $(3 \mu \mathrm{mol})$ and (b) $M$. pruriens $(0.86 \mathrm{mg} / \mathrm{ml})$ in $\mathrm{Ca}^{2+}$-free physiological salt solution. Arrows indicate point of introduction of carbachol or extract.
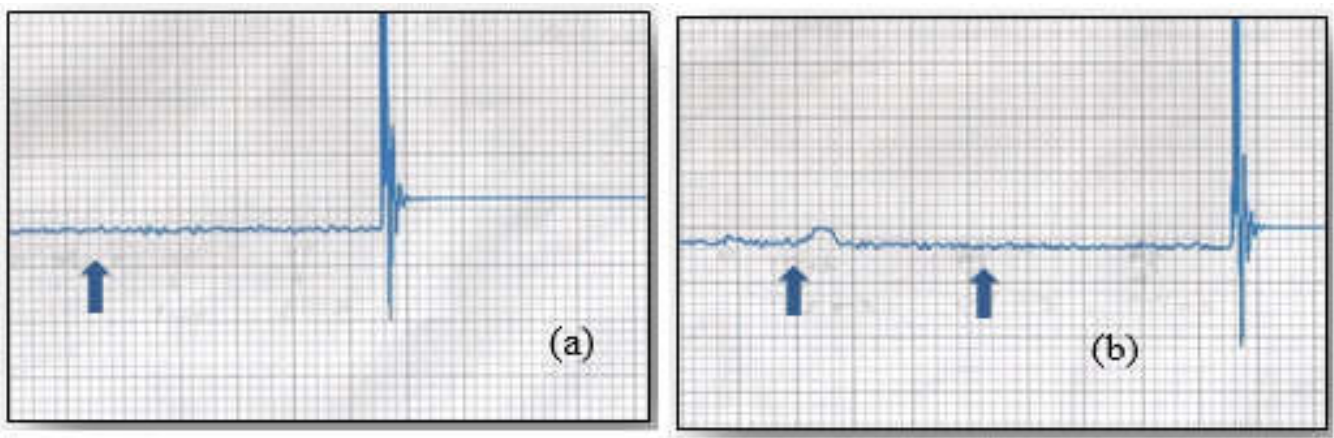

Fig 2: Uterine response to (a) M. pruriens $(0.86 \mathrm{mg} / \mathrm{ml})$ and (b) carbachol $(3 \mu \mathrm{mol})$ in physiological salt solution containing caffeine (4.4 $\mathrm{mmol})$. Arrows indicate point of addition of extract or carbachol.
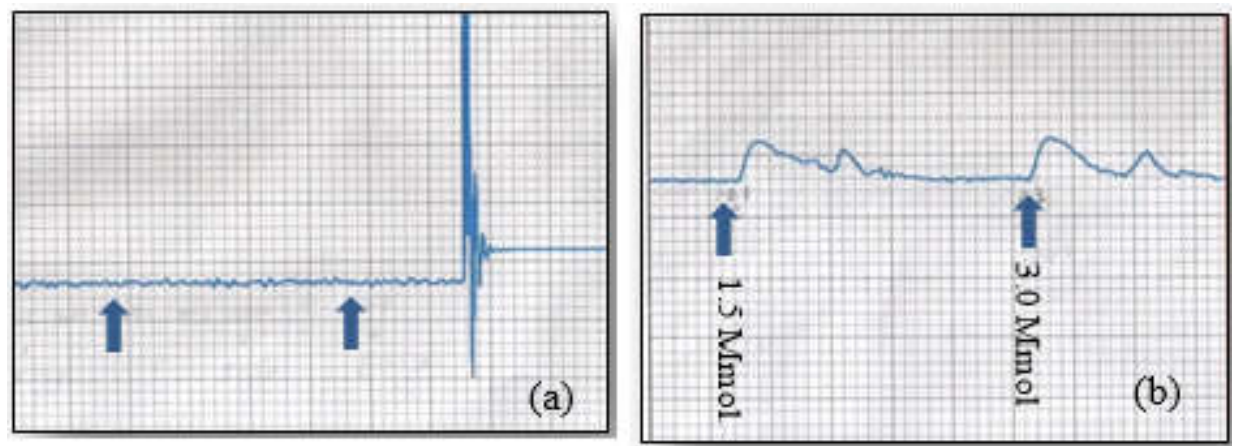

Fig. 3: Uterine smooth muscle response to (a) M. pruriens $(0.86 \mathrm{mg} / \mathrm{ml})$ and (b) carbachol ( $3 \mu \mathrm{mol})$ in physiological salt solution containing lanthanium chloride. Arrows indicate point of application of M. pruriens or carbachol. 
The contractile response to carbachol in the presence of $\mathrm{LaCl}_{3}$ which was much more sustained and of longer duration suggests an increase in the $\mathrm{Ca}^{2+}$ pool and by extrapolation, the contractile proteins within the cell cytosol resulting from inhibition of $\mathrm{Ca}^{2+}$ extrusion and $\mathrm{Ca}^{2+}$ release from intracellular storage sites. It has been suggested that the release of $\mathrm{Ca}^{2+}$ from sarcoplasmic reticulum is usually accompanied by $\mathrm{Ca}^{2+}$ extrusion and thus irreversible loss of this cation to the extracellular compartment (Leijten and Van, 1986). In addition, $\mathrm{La}^{3+}$ is also thought to affect cellular $\mathrm{Ca}^{2+}$ homeostasis by actions such as releasing $\mathrm{Ca}^{2+}$ from Golgi complexes, thus contributing further to the intracellular $\mathrm{Ca}^{2+}$ pool (Zha and Morrison, 1995).

Table 2: Effects of EGTA (1.5 mmol), Caffeine $(4.4 \mathrm{mmol})$ and $\mathrm{LaCl}^{3+}(3 \mathrm{mmol})$ on uterine smooth muscle force induced by carbachol in nominally $\mathrm{Ca}^{2+}$ - free physiological solution

\begin{tabular}{ll}
\hline Drug & Amplitude (mm) \\
\hline Carbachol + EGTA $(\mathrm{n}=3)$ & $2.33 \pm 0.33$ \\
Carbachol $+\mathrm{Caffeine}^{(\mathrm{n}=3)}$ & $1.67 \pm 0.88$ \\
Carbachol $+\mathrm{La}^{3+}(\mathrm{n}=3)$ & ${ }^{*} 6.30 \pm 0.33$ \\
\hline \multicolumn{2}{c}{${ }^{*}$ Value significantly different at $P<0.05$}
\end{tabular}

Effect of verapamil on M. pruriens and Carbachol induced uterine contractions: Varying concentrations of verapamil $(0.007-0.14 \mu \mathrm{mol})$ in physiological salt solution containing $\mathrm{CaCl}_{2}$ was used as a voltage dependent $\mathrm{Ca}^{2+}$ channel blocker. M. pruriens did not elicit any uterine smooth muscle contraction even at the lowest concentration of verapamil used $(0.07$ $\mu \mathrm{mol})$. However, verapamil suppressed carbacholinduced $(3 \mu \mathrm{mol})$ contraction in a concentration dependent manner; with maximal suppression achieved by $0.14 \mu \mathrm{mol}$ concentration of verapamil (P $<0.05)$ Fig. 4.

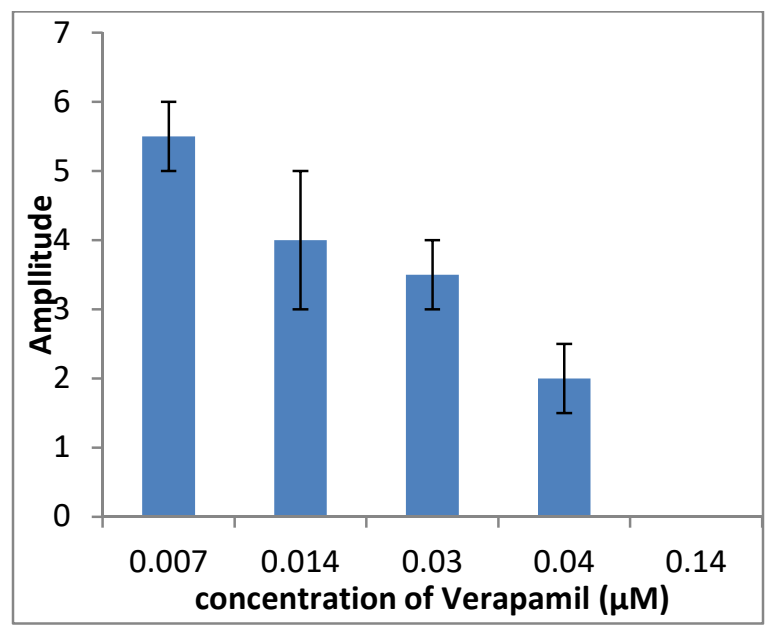

Fig. 4: Effect of graded concentrations of verapamil (0.007- 0.14 $\mu \mathrm{mol})$ on carbachol $(3 \mu \mathrm{mol})$-induced uterine smooth muscle contraction.
Verapamil is a calcium-channel blocking drug that acts by blocking the L-type calcium channels. In those phasic smooth muscles, such as the uterus where action potentials occur, depolarisation and consequent opening of L-type $\mathrm{Ca}^{2+}$ channels make this the major source of $\mathrm{Ca}^{2+}$ for contraction (Matthew et al., 2004). That $M$. pruriens was unable to access $\mathrm{Ca}^{2+}$ in verapamil- containing physiological salt solution is suggestive of the fact that the extract causes calcium entry through the L-type calcium channels alone.

Conclusion: In conclusion, the inability of the extract to produce contractions in $\mathrm{Ca}^{2+}$ - free and in nominally $\mathrm{Ca}^{2+}$ - free media shows that it lacks the ability to mobilize intracellular calcium. Its uterine stimulatory activity is solely dependent on extracellular $\mathrm{Ca}^{2+}$ and therefore, functions through surface receptors.

\section{REFERENCES}

Adepoju GKA; Odubena OO (2009). Effect of Mucuna pruriens on some haematological and biochemical parameters. J. Medic. Plant Res. 3(2): 073-076

Arnaudeau S; Lepretre N; Mironneau J (1994). Oxytocin Mobilises Calcium from a Unique Heparin-Sensitive and Thapsigargin Sensitive Store in Single Myometrial Cells from Pregnant Rats. Pflugers Archiv. 428: 51-59.

Bilge P; Sibel B; Murat D (2013). A Close Look at the Contraction and Relaxation of the Myometrium; the Role of Calcium. J. Turkish-German Gynecol Assoc. 14: 230-4.

Dhanasekaran S; Ratheesh KKS; Palayan M (2010). Effect of Ethanolic Seed Extract of Mucuna pruriens (L.)Dc.Var.Utilis on Haloperidol Induced Tardive Dyskinesia in Rats. Inter $J$. Pharm Sc. Review. Res. 3(2): 106

Eze ED; Mohammed A; Musa KY; Tanko Y(2012). Evaluation of Effect of Ethanolic Leaf Extract of Mucuna pruriens on Blood Glucose Levels in Alloxan-Induced Diabetic Wistar Rats. Asian Journal of Medical Sciences. 4(1): 23-28,

Francis B; Uchendu CN; Obidike RI (2019). Mechanism of Spasmogenic Activity Stimulated by Aqueous Ethanolic Leaf Extract of Mucuna pruriens on Isolated Uterine Muscle of Albino Rats. J of Pharm Res. International. 28(3): 1-10.

Holda JR; Oberti E; Blatter LA (1996). Characterization of an Oxytocin-Induced Rise 
$\mathrm{Ca}^{2+}$ in Single Human Myometrium Smooth Muscle Cells. Cell Calcium. 20: 43-51.

Itoh T; Kuriyama H; Suzuki H (1981). Excitation Contraction Coupling in Smooth Muscle Cells of the Guinea Pig Mesenteric Artery. J. Physiology. 321: 513-535.

Izumi H. (1994). $\mathrm{Ca}^{2+}$ Modulation System of Myometrial Contraction during Gestation, in: Garfield RE; TabbTN (Eds.), Control of Uterine Contractility. CRC Press, Boca Raton, FL. 173205.

Leijten PA; Van BC (1986). The Relationship between Noradrenaline-Induced Contraction and $\mathrm{Ca}^{2+}$ Efflux Stimulation in Rabbit Mesenteric Artery. British Journal of Pharmacology. 89:739-747.

Lynn S; Morgan JP; Gillespie JI; Greenwell JR (1993). A Novel Ryanodine-Sensitive Calcium Release Mechanism in Cultured Human Myometrial Smooth Muscle Cells. FEBS Letters. 330:227230.

Matthew A; Shmygol A; Wray S (2004). $\mathrm{Ca}^{2+}$ Entry, Efflux and Release in Smooth Muscle. Biol. Res. 37: 617-24.
Savineau JP; Mironneau J (1990). Caffeine Acting on Pregnant Rat Myometrium: Analysis of its Relaxant Action and its Failure to Release $\mathrm{Ca}^{2+}$ from Intracellular Stores. British Journal of Pharmacology. 99: 261-266.

Sharma BK; Shamim A; Singh R (2012). A review on M. pruriens: Its phytoconstituents and therapeutic uses. Novel Sci. Int J Pharm Sci. 1(6): 308-312.

Uchendu CN (1999). Role of $\mathrm{Ca}^{2+}$ on Uterine Force Stimulated by a Glycoside from the Root of Dalbergia saxatilis. Indian Journal of Physiology and Pharmacology. 43 (2): 171-178.

Webb RC (2003). Smooth Muscle Contraction and Relaxation. Advances in Physiology Education. 27(4): 201-206.

Wray S; Jones K; Kupittayanant S; Matthew AJ; Monir-Bishty E; Noble K (3003). Calcium Signaling and Uterine Contractility. J. Soc. Gynecol. Investig. 10: 252-64.

Zha X; Morrison GH (1995). Ion Microscope Evidence that $\mathrm{La}^{3+}$ Releases $\mathrm{Ca}^{2+}$ from Golgi complex in LLL-PK1 Cells. Am. J. Physiol. 269: 923-928. 